\title{
Pathological Effects of Crud Trichothecenes on Swiss Mice
}

$$
\text { التأثيرات الأمراضية لسم الترايكوثيسين الخام على الفئران المختبرية }
$$

Noor hashim

Khulood Al-Samarrae

Biotechnology Research Center/ Al-Nahrain University

* College of Medicine / Baghdad University

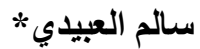

$$
\begin{aligned}
& \text { خلود السامر ائي } \\
& \text { مركز بحوث التقنيات الأحيائية / جامعة النيائ النهرين } \\
& \text { * كلية الطب / جامعة بغداد / جادعة }
\end{aligned}
$$

Abstract

Trichothecenes are natural secondary metabolites causing economic losses and health hazard to human and farm animals which are produced by several species of Fusarium and some other genera on different agricultural commodities. Study on trichothecenes mycotoxicosis revealed morphological, biochemical, and histopathological changes. After intraperitoneal injection of the toxin in male mice with different concentration for 35 days shows marked increase in body weight, dyspanea, shivering, bristling up of hair, hair falling, anomalies of eyes, and irritation around neck, also abdominal hemorrhage and clot accumulation in abdomen. In addition to inclusion (retention) cyst forms on liver. The biochemical studies on liver function by measuring GPT and GOT enzymes level have been done. An increase level of these enzymes in treated animal in comparison with control animal which indicating abnormal function of liver observed. The histopathological study on sections from the liver of treated animal with trichothecenes revealed many alterations in liver which includes congestion, kupffer cells hyperplasia, dilated sinusoids and mononuclear cells infiltration around the portal area.

تعد الترايكوثيسينات من النواتج الأيضية الطبيعية الثانوية التي تسبب خسائر اقتصادية و خطر صحي على التى

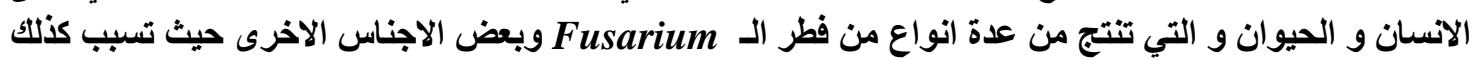

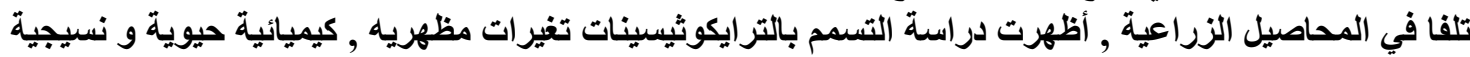

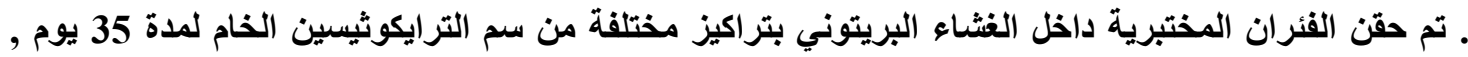

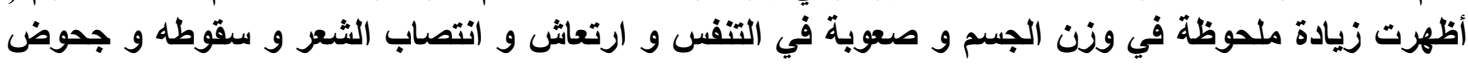

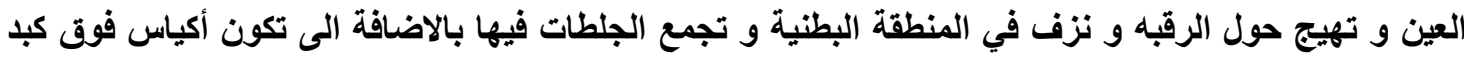

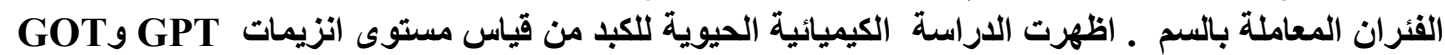

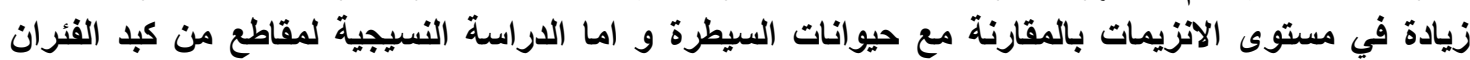

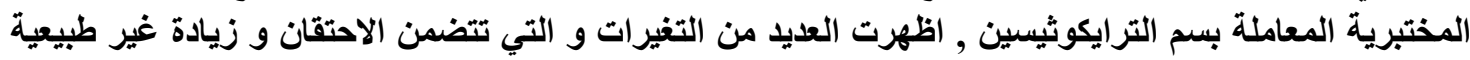

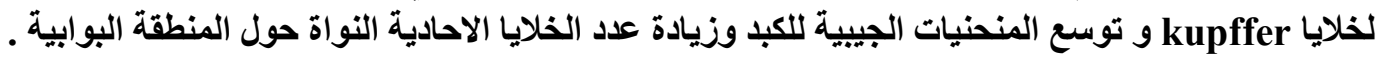

\section{Introduction}

Mycotoxins are important fungal secondary metabolites with low molecular weight; they are representing a potential threat to human and animal. Mycotoxins present a challenge for scientists working on a wide range of disciplines such as microbiology, biochemistry, 
structural chemistry, toxicology, pharmacology and genetics. Trichothecenes are about 148 type of closely related mycotoxins which are widely distributed in nature such as T-2 toxin, Diacetoxyscirpenol (DAS), Deoxynivalenol(DON) and HT-2 toxin. Trichothecenes are group of metabolites produced by species of the genus Fusarium, in addition to other genera including Mythecium, Trichothecium, Verticimonosporium, Cefalosporium, Trichoderma, Gibberella, and Stachybotrys [1].

The fate of Trichothecenes differs according to type of toxin and the animal receiving it. Generally muscle, liver and kidney much likely to be the target organs, for example, in pigs administered with HT-2 toxin, the percentage of administered radioactivity showed that muscle, liver, bile and kidney were the most target organs [2].

Trichothecenes comes after aflatoxin in toxicity and it affects both man and animal.This mycotoxin affects cereal grains, farm animal which consume contaminated feed, also affects man causing diseases, such as Alimentary Toxic Aleukia and Skeletal affliction (Kashin-Back disease)[3]. T-2 toxin is considered as one of the most toxic and common toxin in trichothecenes which is used in biochemical warfare and implicated in "Yellow Rain" used in Southeast Asia [4].

Many diseases reported after ingestion of moldy feed, these diseases characterized by feed refusal, depression, diarrhea, vomiting, and hemorrhage in intestine and muscles which lead to death of animals [5].

\section{Materials and Methodes}

\section{1-Isolation and Identification of Fusarium oxysporum}

The fungi isolated according to [6] about 30 randomly selected corn seeds were surface sterilized then seeds were cultured on Potato Dextrose Agar (PDA), 2 seeds for each plate then incubated at $25^{\circ} \mathrm{C}$ for 7 days, then the grown Fusarium (Which was morphologically identified) purified by new subculturing (each one in single plate of Potato Sucrose Agar (PSA)) this purified isolates were used for identification.

Pure isolates were identified by direct examination with light microscope on glass slide and according to taxonomic system of Snyder and Hansen [7, 8].

\section{2-Production, Extraction and Identification of Trichothecenes}

To produce trichothecenes, spore suspension prepared according to [9], PDA inoculated with spore suspension $\left(8.1 \times 10^{\circ}\right.$ spore $\left.\backslash \mathrm{ml}\right)$ and incubated at $25^{\circ} \mathrm{C}$ for 1 week and at $27^{\circ} \mathrm{C}$ for 1 week and then at $8{ }^{\circ} \mathrm{C}$ for 1 week. And according to [10], toxin extracted and kept in small vials in dry and cold place. By using TLC method trichothecenes have been detected and identified in comparison with standard T-2 toxin using benzene: acetone in 3:2 ratios as developing system for separation of trichothecenes and examined under U.V. light at 366(nm) Wave length (W.L.) with determination of Rf value [11], the amount of toxin was estimated in comparison with standard toxin using scanning densitometer [12]. 


\section{3-Confirmatory test}

According to [13] confirmatory test of trichothecene was done by using aluminum chloride solution cooled and examined under U.V. light at 366-wave length, the Rf value was estimated in comparison with standard toxin.

\section{4-Laboratory animals}

Mature Swiss mice, males and weighted (20.9-22.4) gr. were used in this study, those mice were divided into 4 groups (6 mice for each group) which injected intra peritoneal (IP) as following:-

Group I:Mice were treated daily (IP) with $0.1 \mathrm{ml}$ of $10 \%$ chloroform for 35 days (5 weeks) and considered as control for low dose group.

Group II:Mice were treated daily (IP) with $0.1 \mathrm{ml}$ of toxin $(0.75 \mathrm{mg} / \mathrm{ml})$ for 35 days $(5$ weeks) and considered as low dose group.

Group III:Mice were treated daily (IP) with $0.3 \mathrm{ml}$ of $10 \%$ chloroform for 35 days (5 weeks) and considered as a control for high dose group.

Group IV:Mice were treated daily (IP) with $0.3 \mathrm{ml}$ of toxin $(0.75 \mathrm{mg} / \mathrm{ml})$ for 35 days $(5$ weeks) and considered as high dose group.

After treatment blood sample were taken by heart puncture also kidneys were taken and stored in $10 \%$ formalin.

\section{5-Biochemical study}

The glutamic transaminase enzymes including serum glutamic oxaloacetic transaminase (GOT) and serum glutamic pyruvic transaminase (GPT), measured by using the GOT and GPT- Kits.

\section{6-Histopathological study}

Samples were fixed in $10 \%$ formalin for $24 \mathrm{hr}$ to be prepared for histopathological sectioning [14].

\section{Resultes and Discussion}

\section{1-Isolation and Identification of F. Oxysporum}

Maize has been selected as a natural source for isolation of $F$. oxysporum, when maize put on surface of PDA media gave a good result for isolation of F. oxysporum [7].

The average growth rate of cultures was about $5 \pm 0.5 \mathrm{~cm}$, the fungus is represented by white mycelium on the surface of the dish, but with purple to brownish tinge. Microconidia born on simple phialides arising laterally on hyphae or from short branched conidiophores. Generally microconidia abundant, cylindrical, straight and 1-2 septate.

Macroconidia are born on more branched conidiophores, they were thin walled, 3-5 septate and pointed at both ends, this results obtained according to [8].

\section{2- Production and extraction of trichothecenes}

The isolated fungi proved to be efficient producer for trichothecenes $(750 \mathrm{ppb})$ in comparison with other isolates used for production of trichothecenes [15]. 
According to our experimental work, the method used was a suitable method for recovery of the toxin from the culture, which is characterized by clear red to pink fluorescence of trichothecene derivatives under U.V. light $(366 \mathrm{~nm})$ with Rf value 0.2 on silica gel plate after developing the chromatogram. The solvent system is efficient in separation the components of fungal culture extract.

\section{3- Toxicity of crude trichothecenes}

Marked increase in body weight was observed in treated mice when compared with the body weight of control animal, this increase sustended during the duration of treatment, these observations became slowly appeared in the last week, but in general they were dose dependent [16].

Body weight has significantly increased for high dose treated mice from $21.8 \pm 0.36 \mathrm{~g}$ to $28.2 \pm 0.85 \mathrm{~g}$, and for low dose treated animals from $22.4 \pm 0.37 \mathrm{~g}$ to $26.9 \pm 0.31 \mathrm{~g}$ and that increase is significant according to ANOVA $(<0.05)$ as shown in Table (1).

Table (1): Body weight of mice groups:

\begin{tabular}{|c|c|c|c|c|c|c|c|c|c|c|c|c|}
\hline $\begin{array}{l}\text { Animal } \\
\text { Groups }\end{array}$ & \multicolumn{2}{|l|}{1 day } & \multicolumn{2}{|l|}{7 days } & \multicolumn{2}{|c|}{14 days } & \multicolumn{2}{|c|}{21 days } & \multicolumn{2}{|l|}{28 days } & \multicolumn{2}{|l|}{35 days } \\
\hline Group I & \multicolumn{2}{|l|}{ A } & \multicolumn{2}{|l|}{ A } & \multicolumn{2}{|l|}{ A } & A & & \multicolumn{2}{|l|}{ A } & \multicolumn{2}{|l|}{ A } \\
\hline & 20.83 & \pm & 21.46 & \pm & 21.98 & \pm & 22.63 & \pm & 23.26 & \pm & 23.95 & \pm \\
\hline & 0.41 & & \multicolumn{2}{|l|}{0.38} & \multicolumn{2}{|l|}{0.35} & 0.33 & & \multicolumn{2}{|l|}{0.3} & \multicolumn{2}{|l|}{0.3} \\
\hline \multirow[t]{3}{*}{ Group II } & $\mathrm{A}$ & & \multicolumn{2}{|l|}{ B } & \multicolumn{2}{|l|}{ B } & B & & \multicolumn{2}{|l|}{ B } & \multicolumn{2}{|l|}{$\mathrm{B}$} \\
\hline & 22.3 & & \multicolumn{2}{|l|}{23.18} & \multicolumn{2}{|l|}{24.1} & 25.15 & & \multicolumn{2}{|l|}{26.31} & \multicolumn{2}{|l|}{27.21} \\
\hline & \pm 0.3 & & \multicolumn{2}{|l|}{ \pm 0.37} & \multicolumn{2}{|l|}{ \pm 0.4} & \pm 0.4 & & \multicolumn{2}{|l|}{ \pm 0.37} & \multicolumn{2}{|l|}{ \pm 0.35} \\
\hline \multirow[t]{3}{*}{ Group III } & $\mathrm{AB}$ & & \multicolumn{2}{|l|}{ A } & \multicolumn{2}{|l|}{ A } & A & & \multicolumn{2}{|l|}{ A } & \multicolumn{2}{|l|}{ A } \\
\hline & 21.25 & \pm & 21.76 & \pm & 22.43 & \pm & 22.9 & \pm & 23.56 & \pm & 24.28 & \pm \\
\hline & 0.17 & & 0.19 & & \multicolumn{2}{|l|}{0.17} & 0.13 & & \multicolumn{2}{|l|}{0.13} & 0.12 & \\
\hline \multirow[t]{3}{*}{ Group IV } & $\mathrm{AB}$ & & $\mathrm{AB}$ & & B & & B & & B & & B & \\
\hline & 21.85 & \pm & 22.62 & \pm & 23.9 & \pm & 25.9 & \pm & 27.2 & \pm & 28.21 & \pm \\
\hline & 0.36 & & 0.44 & & 0.5 & & 0.72 & & 0.73 & & 0.8 & \\
\hline
\end{tabular}

The increase in body weight of treated mice groups notably larger than in the control groups, this might be resulted from increase in water consumption and feed consumption, or might be attributed to enlargement of organs such as liver, kidney, spleen and pancreas due to mycotoxicosis [17].

Other signs observed for mycotoxicosis were loss of hair, shivering, dyspnea, redness around the neck and bristling of hair. Although of the aggressive behavior of mice, loss of activity observed at the last two weeks of treatment. All signs mentioned have referred to the action of toxin resulted from mycotoxicosis, similar morphological changes were observed in rat fed diet contaminated with aflatoxin B1 [18] which is attributed to the mycotoxicosis. Hemorrhage and clotting accumulation in the internal viscera are other signs of toxicosis; these signs resulted in giving abnormal dark red color for the internal viscera in comparison with control.

Crude toxin cause exudation case for blood vesicles, oozing of blood lead to hemorrhage and oxidation of hemoglobin in the internal viscera (stomach and intestine), also 
formation of clots and their accumulation gave the abdomen abnormal dark red color. This happened for most of the treated mice, but not all of them, this may be due to the difference in the animal behavior, built of body, and microanatomy between mice [19]. Inflammatory (retention) cyst was observed on liver of treated mice and those cysts occurred due to infection of liver or due to necrosis caused by toxicity [20].

\section{4-Biochemical study}

Generally trichothecenes affect the liver function, this effect can be seen in the evaluation of glutamate oxaloacetate transaminase (GOT) and glutamate pyruvate transaminase (GPT) enzymes level in blood of treated mice, the effect is dose dependent Table (2). Treatment with the toxin induced hepatotoxicity by developing hepatic lesion which leads to this increase in enzymes level [21].

Similar results demonstrated by using aflatoxin B1 on chicken induced significant increase in GOT and GPT level causing them liver disfunctioning due to mycotoxicosis [22].

Table (2): Results of hematological testes:

\begin{tabular}{ccc}
\hline & GPT IU/L & GOT IU/L \\
Group I & A & A \\
& $110 \pm 2.22$ & $23 \pm 1.76$ \\
Group II & $\mathrm{B}$ & $\mathrm{B}$ \\
& $132 \pm 6.14$ & $35 \pm 1.25$ \\
Group III & $\mathrm{C}$ & $\mathrm{C}$ \\
& $195 \pm 9.03$ & $47 \pm 1.58$ \\
\hline
\end{tabular}

\section{Group I: control animals \\ Group II: low dose treated animals \\ Group III: high dose treated animals}

\section{5-Histopathological study (Light microscope examination)}

Trichothecenes affects cell division, damage and death of cells or enhancement of the immune system and mechanical movement to control toxic materials and stop their separation or finding other means or ways to do so.

The hepatic cells of animals appeared with congestion and kupffer cells hyperplasia for low dose treated mice Figure (1) after 35 days of treatment with trichothecenes.

Mild mononuclear cells infiltration in the portal area, around the bile duct was noticed in addition to congestion, sinusoidal dilation and kupffer cells hyperplasia Figure $(2,3,4)$ upon treatment with high dose.

Death of liver cells may explain the dilatation of sinusoid [23]. The mononuclear cells infiltration around the portal area can be explained in that those cells represent a defense mechanism against any inflammation and/or any infection with some toxic materials affecting the hepatic cells [24]. Similar effects were observed in liver of rats treated with aflatoxin B1 [18]. 
Kupffer cells hyperplasia means that increased numbers of macrophage cells appeared, this indicates that presence of an inflammation in hepatic cells, the hyperplasia act as a way to limit the inflammation that occurred because of the mycotoxin. Mycotoxicosis with other mycotoxins such as ochratoxin A cause also kupffer cells hyperplasia in rat liver [25].

Hepatotoxicity occurred when fuminsins administrated to rats, cause kupffer cell hyperplasia and inflammatory infiltrate [26]. So we can conclude from all the above results that trichothecenes like many other mycotoxins can affect significantly liver of mice which considered as target organ and cause to several damages, toxicity on cell organelles, increase in GOT and GPT level, organ dysfunction, activation of the immune system and death of the animals, depending on the dose of the toxin and the time of exposure which is revealed by biochemical and microscopical examination.

Fig (1): Liver section of animal treated with low dose of toxin showing congestion (c) and kupffur cells hyperplasia. Haematoxylin and

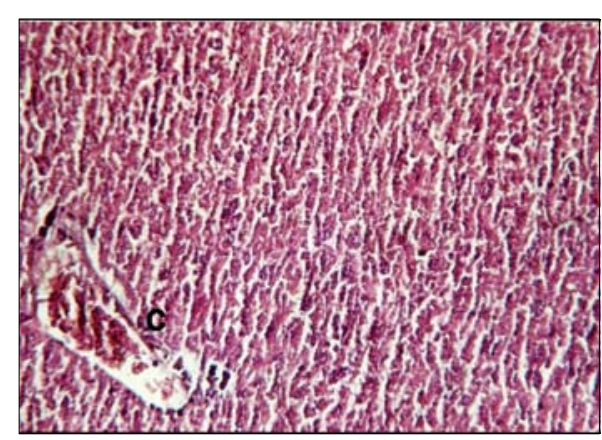

Fig (3) Liver section of mice treated with high dose of toxin showing mild infiltration of mononuclear cells in the portal area, around the bile duct (m). Haematoxylin and Eosin (10X).

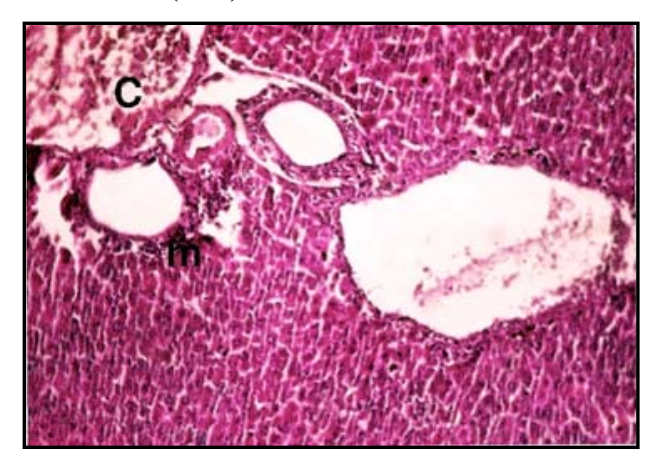

Fig (2): Liver section of animal treated with high dose of toxin showing congestion. sinusoidal dilation and kupffer cells hyperplasia. Haematoxylin and Eosin (40X).

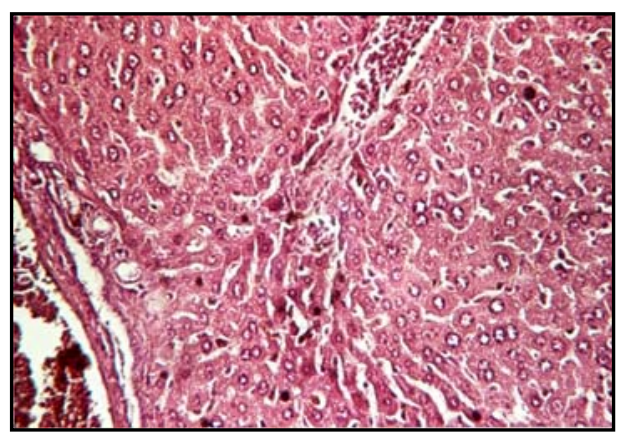

Fig (4) Liver section of animal treated with high dose revealed congestion (c) and inflammation cells infiltration in the portal area, around the bile duct (m). Haematoxylin and Eosin (10X).

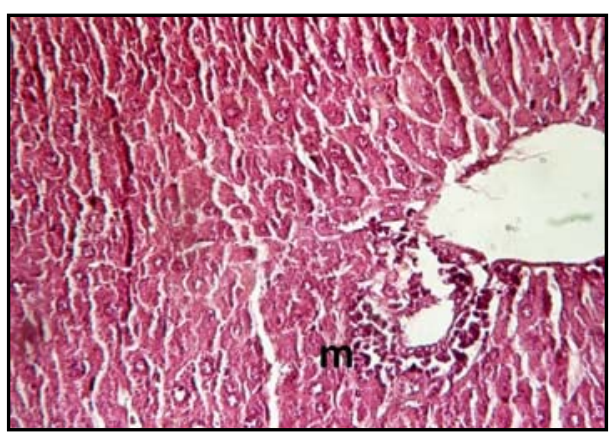




\section{References}

1. Scott,P.M. and Somers,E., (1969). Biologically active compound from field fungi J. Agr. Food chemistry. 17,430.

2. Poapolathep A., Sugita-Konishi Y., Doi K.and Umagai S. (2003). The fates of trichothecene mycotoxins, nivalenol and fusarenon-X, in mice, University of Tokyo, Tokyo113-8657, JAPON.

3. Al-Heety, M. and Abdul-wahid, A. (1992). Fungal toxins, General information, Higher education and scientific research ministry, Baghdad University.

4. Richard C. Dart (2004).Published by Lippincott Williams and Wilkins, ISBN $0781728452,9780781728454$.

5. Danko, G. and Szerafin, J. (1976). Experimental stachybotryotoxicosis in horses. Magy. Allatorv. Lapja, 9: 597-600.

6. Mislivec, P. M., Dierter, C. T. and Bruce, V. R. (1975). Mycotoxin producing potential of mold flora of dried beans. Appl. Microbiol. 29(4): 522-526.

7. Booth, C. (1977). Laboratory guide to the identification of major species, Fusarium, commonwealth mycological institute, Ferry Land, Kew, Surrey, England, 58 pp. illustrated.

8. Tousson, T.A. and Nelson, P.E. (1968). Apictorial guide to the identification of Fusarium spp. According to the taxonomic sys. Of Snyder and Hansen.The Pannsylvania State University Press, Univ. Park and London.

9. Faraj, M.K. (1990). Regulation of mycotoxin formation in Zea mays Ph.D. Thesis, department of bioscience and biotechnology. University of Strathclyde, Glascow. U.K.

10. Ghosal, S., Blswas, K., Srivastava, R.S., Chakrabarti, D.K. and Basuchauhary, K.C. (1978). Toxic substances produced by Fusarium V:occurrence of zearalenon, diacetoxyscirpinol, and T-2 toxin in moldy corn infected with F. moniliform sheld. J. Pharmaceutical. Sci. 67:1769-1788.

11. Betina, V. (1982). Mycotoxins: Production, Isolation, Separation and Purification.

12. Joffe,A.Z. (1965). Toxin production by cereal fungi causing alimentary toxic aleukia in man. In mycotoxins in food-staffs: G.N.Wogan (Ed.). MIT. Press, (Cambridge, Mass)

13. Gimeno, A. (1983). Improved method for TLC analysis of mycotoxin. J. Ass. Off. Anal. Chem. 63: 182-186.

14. Bancroft, J.D. and Stevens, A. (1982). Theory and practice of histological technique. $2^{\text {nd }}$ ed. Churchill Livin Stone.

15. Smith, J. E., Solmans, G. L., Lewis, C. W. and Anderson, J. G. (1994). Mycotoxins in human nutrition and health. Directorate general XII. Sci. Research and development. pp. 168.

16. Dréan , G. Le, Auffret ,M., Batina, P., Arnold, F., Sibiril ,Y., Arzur, D. and ParentMassin, D. (2005). Myelotoxicity of trichothecenes and apoptosis: An in vitro study on human cord blood $\mathrm{CD} 34^{+}$hematopoietic progenitor. 
17. Gibson, R.M., Bailey, C.A., Kubena, L.F., Huff, W.E. and Harvey, R.B. (1989). Ochratoxin A and dietary protein effects in body weight, feed conversion, relative organ weight, and mortality in three week-old broiler. Poult. Sci., 68:1658-1663.

18. Al-Taie, N.H. (2001). Aflatoxin B1 production by local isolates of Aspergillus and it's effect on thymocytes and splenocytes by light and electronic microscope. M.Sc.Thesis, Department of Biotechnology. College of Science. Saddam University.

19. Kuhn, D.M., Ghannoum, M.A. (2003).Indoor mold, toxiginic fungi, and Stachybotrys chartarum : Infectious disease perspective."Clin Microbiol 16:144-172"

20. Ryu, J.-C., Ohtsubo, K., Izumiyama, N., Nakamura, K., Tanaka, T., Yamamura, H., and Ueno, Y. (1988). The acute and chronic toxicities of nivalenol in mice. Fundam. appl. Toxicol., 11: 38-47.

21. Philips, R. (1991). Mushrooms of North America (1st ed.). Boston: Little and Brown company.

22. Petkova R., Tacheva T. and Borisova L. (1985). Para clinical research on broiler chickens treated with Aflatoxin B1 \& microbiological studies on the meat \& liver obtained from them, 22(10):58-64.

23. Newberne, P.M. and Butler, W. H. (Ed). (1978). Rat hepatic neoplasisa. MIT, Press, Cambridge, Mass.

24. White, R., Mela, L., Bacalzo, V., Olofsson, J. K. and Miller, D. (1973). Hepatic ultrastructure in endotoxemic, haemorrhage and hypoxia: emphasis on mitochondrial changes. J. Surgury. 73(4):525-534.

25. Al-Naimi, E.H. (2001). The effect of Ochratoxin A production by Aspergillus ochraceus on the liver of rat- A light and Electronic Microscopic Study. M.Sc.Thesis, Department of Biotechnology. College of Science. Saddam University.

26. Bondy, G.S, Suzuki, C.A., Mueller, R.W., Fernie, S.M., Armstrong, C.L.and Hierlihy, S.L. (1998). Adminstration of fungal toxin FumonisinB1 to female Sprague-Dawley rats. J. Environ Health (part A). 53:135-151. 